\title{
XVI. Yüzyılda İrle Kazası Vakıfları
}

\author{
The Waqfs of Irle District in the $16^{\text {th }}$ Century
}

\author{
Behset KARACA * \\ Durmuş Volkan KARABOĞA*
}

\begin{abstract}
Öz: İrle veya günümüzdeki adıyla Yeşilova ve çevresindeki vakıflarla ilgili bilgileri vakıf defterlerinden öğrenmekteyiz. XVI. yüzyılda burayla ilgili üç defterde bilgi verilmektedir. 1501, 1530 ve 1570-71 tarihli defterlerde buranın vakıfları detaylı şekilde açıklanmıştır. İrle kaza olarak geçmektedir. Bu ad altında belirli bir yerleşim alanı yoktur. Salda Gölü ile Yarışlı Gölü arasında uzanan bölge İrle Ovası olarak anılmaktadır. Ancak, İrle adı incelediğimiz dönemde bugünkünden daha farklı bir bölgeyi ifade etmek için kullanılmıştır. XVI. yüzyılda İrle, Salda ile Yarışlı Gölü arasındaki ovanın hemen kuzeyindeki Dereköy, Beyköy, Alanköy, Akçaköy, Örencik ve Bayındır köyleri ile Akgöl’ü içine alan bölge ile Hambat yöresini içine alan coğrafyanın adıdır. Buradaki köyler de bir kaza oluşturmuşlardır. Köylerin bir kısmı vakıf defterlerinde geçmekte ve buralarda mescid, cami, zaviye ve medrese gibi sosyal yapılar hizmet vermektedir. Vakıf defterlerinde geçen köyler ise Alan, Dere, Akçaköy, Baradız, Beyler, Gölcük, Yazır, İ̆gdir, Bayır, Çardak, Çavdır, Yüreğir, Pamuklu, Büğüş köyleridir. Baradız nahiye olarak da geçmekte ve Gölcük ile Kürt köyleri buraya bağlı görülmektedir. Buradaki vakıfların önemli bir kısmı zaviye vakfıdır. Bazı vakıfların Hamidoğulları'ndan kaldığı ve Osmanlılar tarafından da kullanıldığını görmekteyiz. Bu durum devletlerdeki ve medeniyetteki devamlılığı da göstermektedir. Vakıf defterlerine dayanarak bu kazanın sosyo-kültürel durumunu ortaya koymaya çalıştık.
\end{abstract}

Anahtar sözcükler: Vakıf, Vakıf Defterleri, Zaviye, Salda, Hamid Sancağı, Yeşilova

Abstract: Information concerning the waqfs of Irle (present name Yeșilova) and the surrounding areas is obtained from the waqf registers. For the $\mathrm{XVI}^{\text {th }}$ century information concerning this area is contained in three registers dated 1501, 1530 and 1570-71, where the waqfs of this area are described in detail. Irle is described as a township (district) and there is no particular settlement under this name. The area between Salda Lake and the Yarışlı Lake is described as the Irle Plain. However, the name Irle was used to describe a different region than the present one. In the XVI ${ }^{\text {th }}$ century, Irle, Salda, and just north of the plains between Lake Yarerek Dereköy, Beyköy, Alanköy, Akçaköy, Örencik and Bayındır villages, and the region that includes Akgöl and Hambat were within this region. The villages here comprised a township. Some of the villages are listed in these waqf registers together with social structures such as: masjids, mosques, zaviye and madrasah that served the inhabitants of these villages. The villages mentioned in these waqf registers are: Alan, Dere, Akçaköy, Baradız, Beyler, Gölcük, Yazır, Igdir, Bayir, Cardak, Cavdar, Yuregir, Pamuklu, Bugus. Baradız passes also as a township, and Gölcük and Kurdish villages are seen be attached to it. An important part of these waqfs is the zaviye waqf. We can see that some waqfs continued from the period of the Hamidogulları into the Ottoman XVI ${ }^{\text {th }}$ century. This shows the continuity between states and civilization. In this article the attempt is made to describe the sociocultural status of this township from the evidence contained in the waqf registers.

Keywords: Waqf, Waqf Registers, Zaviye, Salda, Hamid Sanjak, Yeşilova

\footnotetext{
* Prof. Dr. Süleyman Demirel Üniversitesi, Fen Edebiyat Fakültesi, Tarih Bölümü, Isparta. behsetkaraca@sdu.edu.tr, https://orcid.org/0000-0002-5214-3818

** Dr. Öğr. Üyesi, Süleyman Demirel Üniversitesi, Fen Edebiyat Fakültesi, Tarih Bölümü, Isparta. durmuskaraboga@sdu.edu.tr, https://orcid.org/0000-0002-9184-3550
} 


\section{Giriş}

\section{İrle'nin Yeri, Sınırları ve İdari Durumu}

İle ismini bazı araştırmacılar günümüzde Yeşilova'da bulunan Erle ovasına istinaden Erle şeklinde kullanmışlardır. Ancak kelimenin Osmanlıca yazılışına göre değerlendirecek olursak İrle olarak okunması daha uygun olacaktır. Biz bundan dolayı İrle olarak kullandık (Ayrıntı için bk. Ertaş 2012, 153-167). İrle adı altında belirli bir yerleşim alanı yoktur. Salda Gölü’yle Yarışlı Gölü arasında uzanan bölge İrle Ovası olarak anılmaktadır (Arıkan 1988a, 38). Ancak bu ova XVI. yüzyılda İrle kazasına bağlı değildir. Burası Yavice nahiyesi olarak Karaağac-1 Gölhisar kazasına aittir. İrle kazasının sınırları, iki ayrı coğrafi bölgeden meydana gelmektedir. Birinci bölge, Yeşilova'dan Burdur Gölü istikametindeki çizginin kuzeyinde kalan kısımdır. İkinci bölge ise Salda Gölü'nün kuzeybatı istikametindeki dağlık arazi ile Hambat ovasından oluşmaktadır. Buranın Karaağaç-ı Gölhisar kazası ile sınırını Elmadağ oluşturmaktadır. Günümüzde bu bölge Çardak ve Bozkurt ilçelerinin sınırlarına dâhildir. Yani XVI. yüzyılda İrle, Salda ile Yarışlı Gölü arasındaki ovanın hemen kuzeyindeki Dereköy, Beyköy, Alanköy, Akçaköy, Örencik ve Bayındır köyleri ile Akgöl'ü içine alan bölge ile Hambat yöresinden meydana gelmektedir (Ertaş 2012, 153-154).

İrle, 1501, 1523 ve 1530 y1lında kaza, 1568'de ise nahiye olarak kaydedilmiştir. 1568'de birçok kaza defterde nahiye olarak yazılmıştır. Bunun sebebi kaza ve nahiye arasında herhangi bir ayırımın gözetilmemesinden kaynaklanmaktadır. Bu defterin incelenmesiyle de burasının kaza statüsünde olduğu görülmüştür. 1570-71 tarihli vakıf defterinde yine kaza durumundadır. XVI. asırda Hamid Sancağı'nın 10'un üzerinde kazası vardır. İrle de bunlardan birisidir. 1501 ile 1570-71 tarihleri arasında Hamid Sancağ 1 şu kaza ve nahiyelerden meydana gelmektedir: 1501 tarihinde Gölhisar (nahiye-i Karaağaç ile birlikte), İrle, Burdur, Keçiborlu, Gönen, Isparta, Eğirdir (Yuva ile birlikte), Barla (Afşar ile birlikte), Ağlasun, Yalvaç ve Karaağaç, Uluborlu kazalarından oluşmaktadır (BOA, TT 994, 1-406; Karaca 2012, 44). 1523 tarihinde, Karaağaç-1 Gölhisar (nahiye-i Yavice ile beraber), Gölhisar, İrle, Burdur, Uluborlu, Keçiborlu, Gönen, Isparta, Ağlasun, Eğirdir (nahiye-i Anamas, Yuva ve Kartas ile beraber), Afşar, Yalvaç, Karaağaç kazalarından müteşekkildir (BOA, TT 121, 1-573; Karaca 2012, 44-45). 1530 tarihinde, Karaağaç-1 Gölhisar ma'a nahiye-i Yavice, İrle, Gölhisar, Burdur, Uluborlu, Keçiborlu, Gönen, Isparta, Ağlasun, Eğirdir ma'a Yuva, Afşar ma’a nahiye-i Barla, Yalvaç ma’a nahiye-i Karaağaç kazalarından meydana gelmektedir (BOA, TT 438, 246-331; 438 Numaralı Muhasebe-i Vilayeti Anadolu Defteri (937/1530) 1993, 246-331; Karaca 2012, 45). 1568 tarihli defterin fihristinde ise Hamid Sancağı 20 yönetim birimine ayrılmıştır. Bunların hepsi nahiye olarak isimlendirilmiştir. Fakat bunların bir kısmının kaza olduğunu defterin incelenmesiyle görmekteyiz. Bu tarihte Hamid Sancağı, Karaağaç-1 Gölhisar (Acıpayam), Yavice, Gölhisar, Siroz ve Kemer, İrle, Burdur, Keçiborlu, Gönen, Uluborlu, Yalvaç, Karaağaç, Afşar, Eğirdir, Anamas, Yuva, Kartas-1 Feryas (?), Hoyran, Barla, Isparta ve Ağlasun şeklinde idari birimlerden meydana gelmektedir (TKGMA, TT 51, 1; Karaca 2012, 45). 1570-1571 tarihli vakıf defterinin fihristinde de Hamid Sancağı'nda şu idari birimler yer almaktadır. Gölhisar Karaağacı, İrle, Burdur, Isparta, Ağlasun, Eğirdir, Barla, Afşar, Karaağaç, Yalvaç, Uluborlu, Keçiborlu, Gönen. $\mathrm{Bu}$ idari birimlerin hangisinin kaza hangisinin nahiye olduğunu tam olarak bilemiyoruz. Fakat çoğunluğu kaza durumundadır (TKGMA, TT 566, 1-116).

İrle ve çevresindeki yerleşimler, çok eskilere dayanmaktadır. Buradaki höyükler, iskânın tarih öncesi dönemlere kadar gittiğini göstermektedir. Ancak, XV. yüzylldaki iskân merkezlerinin tümünün Türk dönemine ait olduğu belirtilmiştir. Beyler, Ilıcan, Gemiç, Tutluca, Soğüd, Çaltu ve Çardak gibi köylerin günümüzde de varlığını devam ettirmelerinden dolayı yerleri bilinmektedir. Ancak Örenlü (Ürünlü), Üreklü, Panbuklu, Kozluca gibi köylerin yeri tespit edilememiş̧ir. XVI. yüzyılda Beyler en büyük köy olup kazanın merkezi durumundadır. 
Vakıflar yönünden de en fazla sosyal ve kültürel müesseseler buradadır (Ertaş 2012, 155). Çardak, Söğüd, Gölcük gibi köyler de Hambat yöresinin önemli köyleridir. Panbuklu, Büğüş ve Karaağıl köylerinin ise günümüze kadar gelemediği tespit edilmiştir (Ertaş 2012, 153-167). 1478 'de İrle kazasına 33, 1523'de 28 ve 1568 yılında ise 36 köy dâhildir (Arrkan 1988a, 65). Köylerde ise 1478 'de 569 nefer, 61 çift, 229 nim çift, 177 bennak ve 22 mücerred kayıtlıdır. 1523 'de 613 nefer, 372 hane ve 136 mücerred yazılmıştır. Yine 1523'de Çardak, Çepni, Düdendelüsü, İğdecükdelüsü, Karamahmud ve Kulak cemaatleri bulunmaktadır. Bu cemaatlere 382 nefer, 200 hane, 166 bennak, 142 mücerred, 1 çift ve 85 de muaf zümre kaydedilmiştir. 1568 yllinda ise 1776 nefer, 1012 hane ve 572 mücerred ve 83 sipahizade kaydedilmiştir. Mesela bu verilere dayanarak 1523 'de 3000,1568 'de de 6000 civarında kişinin yaşadığını tahmin edebiliriz (Arıkan 1988a, 74-76; Karaca 2007a, 120-121). Bu göstergelerle, köy sayıs1, nüfusu ve vakıflarının adediyle orta büyüklükte bir kaza olduğu görülmektedir. 1530'da İrle kazasının müstakil bir kadısı bulunmamakta ve Burdur ile İrle'ye aynı kadı bakmaktadır. Bu iki kaza 30 akçelik bir kadılıktır. Bu dönemde Karaağaç-1 Gölhisar 20, Gölhisar 40, Uluborlu 25, Gönen ve Keçiborlu 25, Isparta 20, Ağlasun 15, Eğirdir 50, Yalvaç ma’a nahiye-i Karaağaç 35 akçelik kadılıklardır (TT 438, 246-331; 438 Numaralı Muhasebe-i Vilayet-i Anadolu Defteri (937/1530) 1993, 246-331). Vakıf defterlerinde geçen köyler ise Alan, Dere, Akçaköy, Baradız, Beyler, Gölcük, Yazır, İğdir, Bayır, Çardak, Çavdır, Yüreğir, Pamuklu, Büğüş köyleridir. Baradız nahiye olarak da geçmekte ve Gölcük ile Kürt köyleri buraya bağlı görülmektedir.

Kısaca İrle'nin Hamidoğulları'ndan itibaren tarihinden bahsetmek gerekirse şunları söyleyebiliriz: Feleküddin Dündar Bey, dedesi Hamid Bey ve babası İlyas Bey'in ölümünden sonra Hamidoğulları Beyliği'nin idaresini eline geçirmiş ve hükümet merkezini de Uluborlu'dan Eğirdir'e taşımıştır. Feleküddin Dündar Bey bir hayli eserle Eğirdir'i imar ederek kendi künyesine nispetle Felekabad adını vermiştir (Uzunçarşı1ı 1984, 62). Feleküddin Dündar Bey daha sonra, İrle (Yeşilova), Asikaraağaç veya Garbikaraağaç ve Tefenni’yi ele geçirerek topraklarını batıya doğru genişletmiştir. Fakat Moğolların fazla dikkatini çekmemek için onlar adına 1309-1310 tarihlerinde Felekabad, Burdur ve Burgulu (Uluborlu)'da gümüş sikkeler kestirmiştir. Görüldügü üzere, İlhanlılara bağlılık şeklen de olsa devam etmektedir. 1308 yıllarında bugünkü Burdur ve Isparta illerinin bulunduğu hemen hemen bütün bölge Hamidoğulları'nın eline geçmiş durumdadır. İrle de bu tarihlerde Beyliğin eline geçmiş olmalıdır (Kofoğlu 2006, 161-162). Osmanlıların eline geçmesi ise Yıldırım Bayezid zamanında 1391 tarihinde gerçekleşmiştir. Antalya ve çevresinin Osmanlı hâkimiyetine geçiş tarihi birçok müellif tarafından farklı verilmesine rağmen Yıldırım Bayezid zamanında alındığ İsa Çelebi'ye sonra da diğer oğlu Mustafa Çelebi'ye sancak olarak verilmesi konusunda hiçbir şüphe yoktur. Birçok vakıfta Teke Beylerinden sonra, Bayezid Bey hünkârdan, İsa ve Mustafa Çelebi'den nişan (berat, misal, biti) alanların isimlerinin kaydedilmesi bunu teyit etmektedir. Hamidoğulları'nın Antalya şubesi de 1392 tarihinde fethedilecektir (Cezar 2010, 24; BOA, KK 3357, 2-10; BOA, MAD 14, 412/b-434/b; Karaca 2002a, 43-44). Ancak bu bölgenin kesin olarak Osmanlılara geçmesi ve bölgede huzur ve istikrarın tam olarak sağlanması 1397'de Karamanoğlu Alâeddin Ali Bey'in Akçay Savaşı'nda mağlup olup öldürülmesinden sonra olacaktır (Tekindağ 1997, 316-330). İlk olarak 1391-1392 tarihinde fethedilen Hamid-ili, Ankara Savaşı'ndan sonra tekrar Osmanlıların elinden çıkmıştır. Daha sonra 1423 tarihinde Antalya şubesi de dâhil olmak üzere Hamidoğulları Beyliği tamamen Osmanlıların eline geçmiştir. İrle ve çevresi de böylece son kez Osmanlılara geçmiştir. Hamid bölgesi, II. Murad zamanında Anadolu Eyaleti'ne ithal edilmiş ve daha sonraki zamanlarda da bu durumunu muhafaza etmiştir (Ahmed Refik 1340, 69; Uzunçarş11 1984, 69; Kofoğlu 2006, 292-297; Cezar 2010, 24; Karaca 2012, 19-42). Bu bölgenin Osmanlı Devleti'nin eline geçmesiyle burada istikrar ve huzur sağlanmış ve 1511 yılında Antalya'da çıkan Şahkulu İsyanı'na kadar uzun süre problemle karşılaşılmamıştır. Şahkulu İsyanı Antalya ve çevresi başta olmak üzere Hamid 
Sancağı'nı da etkilemiştir (Bu konuda bk. Arıkan 1988a, 20-22; Karaca 2001, 457-472; 2002a, 46-51; 2002b, 409-418; 2003, 71-86; 2005, 17-36; 2007b, 759-774). Buradan bunun sonucunda göçler veya sürgünler olmuştur. Bu göçler ya da sürgünler sonucunda bölgedeki bazı köyler boşalarak mezraya dönüşmüştür. Özellikle Gölhisar, İrle, Uluborlu, Ağlasun kazalarındaki bazı köylerin halkının Sürh-ser (Kızılbaş) olup İran'a gittikleri ve karyelerinin mezraya dönüştüğü görülmektedir. İrle'de mezraya dönüşen yerlerde şu tarzda kayıtlar vardır: "Mezra-i Kozluca defter-i köhnede karye olub reayası surh-ser olub mezra kayd olundu. Hâsıl 700". "Mezra-i Emrudlar defter-i köhnede karye olub reayası perakende olmağın mezra kayd olundu. Hâsıl 1009". "Mezra-i Çaltu defter-i köhnede karye olub reayası perakende olmağın mezra kayd olundu. Hâsıl anil galle ve gayre 1708”. (Ayrıntı için bk. TT 438, 262; 438 Numaralı Muhasebe-i Vilayet-i Anadolu Defteri (937/1530) 1993, 262; Arıkan 1988a, 20-22; Karaca 2017, 577-593;).

\section{İrle Kazası Vakıflarının Özellikleri, Dağılımı ve Gelirleri}

Vakıf, "kişilerin kendilerine ait menkul veya gayrimenkul mallarını veyahut nakit paraların cemiyetin yararına bağışlamaları" ya da "bir malı şahsi mülkiyetten çıkarmak suretiyle, alımsatıma ve mülkiyete konu olması mümkün olmayacak şekilde insanların istifadesine tahsis etmesi"ne denilmektedir. Böyle bir davranışın arkasında bir mecburiyet ve zorlama değil, dinî ve kültürel değerler bulunmaktadır. Öyleyse İslam vakfını, mali imkân sahibi bir Müslümanın, şahsi mallarından bir kısmını kamu hizmetini görecek kuruluşlara dönüştürmesi fiili olarak tanımlamak da mümkündür. Bunun sonucunda vakıf müessesesi, Türk ve İslâm dünyasının etkisini gösterdiği geniş coğrafyada asırlarca tatbik edilmiş (Ayrıntı için bk. Yediyıldız 1982, 26; Akgündüz 1988, 29-45; Kazıc1 2003, 33; Özcan 2003, 1; Gündüz 2012, 317; Ünal 2013, 245) böylece, Türk tarihinin sosyal, kültürel ve ekonomik hayatında önemli bir rol oynamıştır (Saydam 1995, 188; Yediyıldız 1999, 17).

Osmanlı döneminde toplumdaki sosyal dengenin büyük ölçüde vakıflar tarafından sağlandığını bilmekteyiz. Askeri meselelerde varını yoğunu seferber eden Osmanlı Devleti, devlet bütçesinden sosyal hayata yönelik hiçbir yatırıma girişmemiştir. Devlet kendi bütçesinden medrese, imarethane, cami, mescid, hastane, zaviye, kervansaray, han, hamam, çeşme, muallimhane gibi herhangi bir sosyal tesis yaptırmamıştır. Çünkü Osmanlıya göre bunları yaptırmak devletin görevi değildir. Devletin görevi, vatandaşın can ve mal güvenliğini sağlamak, asayişi temin etmek, sınırları korumak ve devlet düzenini sağlamaktır (zarurat-1 diniye, canın korunmas1, malın korunmas1, aklın korunmas1, neslin korunmas1, vicdanın (dinin) korunması). Devletin birçok bölgesinde bulunan yüzlerce kurum, vakıflar yoluyla hayırseverler tarafindan inşa ettirilmiştir. Klasik dönemde fertlerin yaptırdığ 1 bayındırlık eserleri ve sosyal tesisler toplum hayatını karşılamaya yetmiştir. Ancak Tanzimat'tan sonra devlet bütçesinden okul, köprü, yol, kütüphane vb. şeyler yaptırılmaya başlanmıştır (Ünal 2013, 246).

Vakıf müessesesi, Osmanlı toplum hayatında, iskân, istikrar, şehircilik, eğitim, kültür, sosyal hizmet ve ekonomik açılardan derin izler bırakmıştır (Ayrıntı için bk. Öztürk 2002, 433446). Türk tarihinde en yaygın ve en fonksiyonel olarak uygulandığı dönem ise, hiç şüphesiz Osmanlılar zamanıdır. Osmanlı şehir ve kasabaları fizikî, içtimaî ve iktisadî bakımdan şehre merkezlik eden vakıf kuruluşları etrafında gelişmişlerdir (Ayrıntı için bk. Ergin 1939). Hatta kırsal düzenin oluşumunda da vakıf kurumunun önemi büyüktür. Hamid Sancağı'nın şehirleri ve kırsal alanının şekillenmesinde de vakıflar etkili olmuştur. Osmanlı Devleti'nin toprakları çarpıcı biçimde vakıf medeniyetinin yaratısıdır (Ortaylı 2007, 312). Sancakta 1501'de 216 civarında vakıf eser bulunmaktadır. 1530 tarihinde ise toplam sancakta 303 vakıf vardır. 157071'de ise vakıfların sayısı daha da artmıştır. Bu vakıfların da önemli bir kısmı tekke ve zaviye vakfidır (TT 438, 250-325; 438 Numaralı Muhasebe-i Vilayet-i Anadolu Defteri (937/1530) 1993, 250-325). İrle kazasının bir merkezi ve şehri yoktur. Burası kırsal özellik gösteren bir 
yerdir. Bundan dolayı vakıflar köylerde toplanmış durumdadır. Kazanın merkezi durumunda olan yer daha önce belirttiğimiz üzere Beyler köyüdür.

Osmanlı devri Türk vakıf kurucularının kimliğine bakıldığında, XVII. yüzyılda \%89.13'ünü, XVIII. yüzyılda \%68.45'ini, XIX. asırda ise \%28.34'ünü askeri sinıf denilen Osmanlı yöneticileri oldukları görülmektedir. Bu Osmanlı vakıf kurucularının da büyük çoğunluğunun kapıkulu mensupları oldukları dikkat çekmektedir. Mesela, XVII. asır Osmanlı vakıf kurucularının \%66.44'ü bu zümreye aittir. Bu dönemde tesis edilen ailevi ve yarı ailevi vakıfların \%49.69'u bunlar tarafindan tesis edilmiştir. Ailevi ve yarı ailevi vakıf kurucuların büyük çoğunluğunun devlet hizmetinde bulunan yönetici sınıfa mensup kimselerden oluştuğu ve bunların büyük bir kısmının ya savaş yoluyla veya devşirme sistemiyle alınıp yetiştirildikleri ve sonra yönetimde yer aldıkları görülmektedir. Bunlar haricinde dul kadınların ve reayanın kurduğu vakıfların sayısı ve para hacmi çok değildir (Yüksel 2002, 462-465). Sancakta devlet görevlileri tarafından kurulmuş vakıflar olmakla birlikte, İrle kazasındaki vakıfların böyle devlet görevlileri veya yüksek dereceli devlet adamları tarafindan kurulmadıklarını görmekteyiz. Buradaki vakıf kurucularının büyük çoğunluğunun fakih, kadı, dede, şeyh, halife, Mevlana, paşa gibi unvanlara sahip askeri yani vergi ödemeyen zümrelere ait olduklarını görmekteyiz. Bazı vakıf kurucuları ya kendileri zikrettiğimiz unvanlara ya da fakih, kadı, dede, şeyh, halife, Mevlana ve paşa gibi unvanlara sahip birinin oğulları olarak kayda geçmişlerdir. Bunların isimleri ve zikredildikleri sosyal müesseseler ise şunlardır: Kadı Bedreddin kardeşi İbrahim Fakih (cami), Şeyh İyas (zaviye), Şeyh İbrahim (zaviye), Ali Fakih, Mahmud Fakih ve Muhammed Fakih (vakf-1 âmm), Şeyh Halil, Şeyh İbrahim (1 çiftlik yer), Şeyh İshak ve Şeyh Bayezid (zaviye), Ekmel Fakih (Sevinç çiftliği), Şeyh İsmail, Şeyh Musa ve Ersel b. Şeyh Paşa (zaviye), Mevlana Pir Ahmed (çiftlik-zaviye), Şeyh İlyas oğlu Hızır Fakih (vakf-1 âmm), Onacık Dede, Ferruh Dede, Seraç Dede (zaviye), İskender Halife (cami-medrese) (Bk. Tablo 2).

Vakıf kurucuları arasında dikkatimizi çeken hususlardan birisi de hayırsever kadınların burada bulunmasıdır. Bilindiği üzere Osmanlı toplumunda erkeklerin hâkimiyeti daha ön plandadır. Osmanlı toplumunda kadın vakıf kurucularının \%20 civarında seyretmesi, erkeğin söz sahibi olduğunu göstermektedir (Yüksel 1999, 52). Kırsal kesimde vakıf kurabilecek servet ve birikime sahip kadınlar daha az olmasına rağmen burada vakıf kuran hanımlar bulunmaktadır. Bunlardan birisi Bayır köyünde Aişe Hatun tasarrufunda iki çiftlik yer Hamidoğulları zamanından beri vakfiyet üzere tasarruf edilmektedir. Bu vakıf 1501 ve 1570-71 tarihli defterlerde geçmektedir (MAD 3331, 55; TKGMA, TT 566, 17/b). Yine Rabia Hatun zaviyesi vardır. Beyler köyünde 1570-71 tarihinde kaydedilmiştir (TT 566, 17/b). Aynı dönemde Karaağaç-1 Gölhisar kazasındaki 25 vakıf kurucusundan 4'ü kadındır (Ertaş 2007, 184-185). Bu sayılar az olmakla birlikte böyle kırsal bölgelerde kadın vakıf kurucularının olması önemlidir.

Buradaki bazı vakıfların Hamidoğulları'ndan veya Osmanlıların ilk zamanlarından kaldığını ve kullanıla geldiğini de öğrenmekteyiz. Osmanlı Devleti'nin birçok kurumu daha önceki Türk Devletlerine ve beyliklere dayanmaktadır. Doğal olarak onlardaki birçok yapıyı Osmanlı da kullanmıştır. Devletlerde devamlılık esastır. Bundan dolayı Hamidoğulları ve diğer beyliklere ait araziler fethedildikten sonra mülkler, vakıflar gibi birçok şey Osmanlılar tarafından korunmuş, eski sahiplerine verilmiştir. Bu bölgenin fethiyle de buradaki vakıfların Osmanlıya intikal ettiğini ve beratların yenilenerek eski sahiplerine verildiğini görmekteyiz. İrle kazasında da Hamidoğulları'ndan kaldığı kesin olan vakıflar vardır. Mesela 1501 yılında Yazır köyünde Sevinç Çiftliği, Ekmel Fakih ve kardeşi Muhammedî (Mehmed) ve Mevlânâ Pir Ahmed ve Mustafa'ya babadan, dededen, Hamidoğlu zamanından beri vakıftır. 1530 ve $1570-71$ 'de de bu kayıtlar tekrarlanmıştır (Ayrıntı için bk. MAD, 3331, 55; TT 438, 263; 438 Numaralı Muhasebe-i Vilayet-i Anadolu Defteri (937/1530) 1993, 263; TT 566 16/a; Tablo 2). Yine Aişe Hatun tasarrufunda olan iki çiftlik yer Hamidoğulları zamanından beri vakıftır (Ayrıntı için bk. 
MAD 3331, 55; TT 566, 17/b; Tablo 2). Bunların yanında bazı vakıflardaki ifadelerden bu vakıfların çok eskilere gittiği ve Hamidoğulları'na dayandığını anlamaktayız. Kadîmü'leyyâmdan vakıf olduğunun belirtilmesi (MAD 3331, 53; Tablo 2), defter-i Sultâniyede vakfiyetle mestûr ve mukayyed olub kadîmden selâtîn-i mâzîye ahkâmiyla vakfiyet üzere tasarruf ederler imiş gibi ifadelerin olması da bu vakıfların eskiliğini göstermektedir (MAD 3331, 54; Tablo 2). Özellikle 1501 tarihli defterde buna benzer ifadeleri birçok vakıfta görmek mümkündür (Ayrıntı için bk. Karaca 2014).

Fatih döneminde bazı vakıfların nesh olduğunu biliyoruz. Bunun yapılmasında mali kaynakları arttırma, asker sayısını arttırma ve merkezi yapıyı güçlendirme gibi düşünceler vardır (Ayrıntı için bk. İnalcık 1997; 2000; Yörük 2007). Hamid Sancağı'nda da tımara dönüştürülen mülk ve vakıflar bulunmaktadır. Tapu tahrir ve vakıf defterlerinde bu konuda detaylı bilgi bulunmaktadır (Ayrıntı için bk. Arıkan 1988b; Karaca 2014). İrle kazasında da 3 adet vakıfta bu dönemde nesh olduğu ve sonra tekrar verildiği ile ilgili bilgiler bulunmaktadır. Mesela bir vakıfta, "nesh olup tımara hükm olunduğu, yine başka bir vakıfta nesh olup tebdil ve tağyir olmuş olduğu ve şimdiki halde mezkûr vakfin vakfiyetin kemakân mukarrer tutulduğu, diğer bir vakufta ise defter-i köhnede mestur olduğu sonra nesh olup tebdil ve tağyir olduğu gibi” bilgiler bulunmaktadır (Ayrıntı için bk. MAD 3331, 53-54; Tablo 2).

İrle'deki vakıflarla ilgili bilgileri vakıf defterlerinden öğrenmekteyiz. XVI. yüzyılda burayla ilgili üç defterde bilgi verilmektedir. 1501, 1530 ve 1570-71 tarihli defterlerde buranın vakıfları detaylı şekilde açıklanmıştır. İrle kazası vakıflar yönünden zengin kazalardan birisi değildir. Burada daha ziyade ihtiyaca yönelik cami, mescid, kuyu, medrese, zaviye, musluk, vakf-1 âmm gibi vakıflar bulunmaktadır.

1501 tarihinde kazada 11 vakıf vardır. Bu vakıfların 1'i cami, 4'ü zaviye, 2'si vakf-1 âmm, 3 adet çiftlik vakfi ve 1 tanesi de zamme okumak şartıyla verilen vakıftır. Yani toplamda 11 vakıf vardır.

1530'da 1 cami, 4 zaviye, 2 vakf-1 âmm, 2 adet çiftlik vakfı, 1 zamme okumak için, 1 medrese ve 1 mescid vakfı bulunmaktadır. 1530'da vakıfların sayısı ise 12 olmuştur. Daha önceki tarihe göre mescid ve medrese vakfı eklenmiş çiftlik vakfının birisi ise yazılmamıştır.

1570-71 tarihinde 3 cami, 6 zaviye, 2 vakf-1 âmm, 2 çiftlik, 1 zamme okumak, 1 medrese, 7 mescid, 1 kuyu, 1 musluk ve 3 adet de bir zaviyeye zam edilen vakıf bulunmaktadır. Görüldüğü üzere vakıfların sayısı artmış ve 27'ye çıkmıştır. Ancak 3 vakıf Rabia Hatun zaviyesine zam edildiği için sayı 24'dür. Vakıfların büyüklükleri bulundukları yere ve vakıf sahibinin servetine bağlı olarak değişmektedir. Bu sebeple, kırsal bir bölge olması ve büyük bir yerleşme merkezi bulunmaması dolayısıyla İrle kazasındaki vakıfların çoğu küçük vakıf niteliğindedirler. Kazada dikkati çeken büyük vakıf niteliğinde sayabileceğimiz vakıf 4500 akçelik paranın rıbhının imamla hatibe harcandığı Alan köyündeki Cami-i şerif vakfı, nakit olarak 1530'da 9500 akçe, 30 dönüm zemin ve Bağ-1 Bozyer, 1570-71'de 9300 akçelik Beyler köyündeki Cami-i Şerif, 5000 akçe ve Bozyer bağına sahip olan İskender Halife medresesi, 4400 akçelik nakit para ve Gölhisar kazasından Bügüss ve Horzum köylerinden zam olunan 3 çiftlik yerin 600 akçelik hâsilıyla Rabia Hatun zaviyesi, 1570-71 yılında Akça köyde 2720 nakit paraya sahip mescid ve 2100 akçe nakit parası olan Çardak Mescidi büyük vakıf niteliğindedir. Büyük gelire sahip vakıflar genelde 1570-71 tarihinde kurulmuşlardır (Bk. Tablo 2).

1570-71'de vakıf sayısı artmıştır. Birçok köyde vakıf yer almıştır. Vakıfların yer aldığ köyler: Gölcük, Baradız, Beyler, Yüreğir, Alan, Dere, Akçaköy, Çavdır, Çardak, Bayır, İğdir, Yazır, Kargucak kurbu (Onacık), Kürt, Pamuklu'dur. Bu köylerden Beyler, Akçaköy, Alan, Yazır ve Kürt en çok vakfa sahip olan köylerdir. Beyler'de, zaviye, vakf-1 âmm, medrese, cami, 2 mescid ve musluk vakfı vardır. Akçaköy, Alan, Yazır ve Kürt köylerinde ise ikişer adet vakıf bulunmaktadır. İsmini saydığımız diğer köylerde ise birer adet vakıf vardır. Vakıf bulunan köylerin sosyal ve ekonomik durumu daha iyi durumdadır. 
Köylerde vakıf sayısı kadar vakıf çeşitliği de önemlidir. XVI. yüzyıl başında kazadaki hemen hemen tüm vakıflar cami, zaviye, zamme okumak, vakf-1 âmm ve çiftlik vakıflarıdır. Bunlar görüldüğü üzere dini karakterli vakıflardır. Bu tür vakıfların temel özelliği vakıf hizmetlerinden, köylülerin daha çok vakıf kurucularının bağlı olduğu sosyal tabakaların yararlanmasıdır. Ancak bu yüzyılın ikinci yarısında köylerdeki sosyal, kültürel ve ekonomik düzeyin artmasıyla vakıfların çeşitliliği armış ve bu vakıflara medrese, mescid, su kuyusu, musluk (çeşme) vakıfları eklenmiştir. Hatta daha önce olan vakıfların sayısında da artış meydana gelmiştir.

Tablo 1. 1501, 1530 ve 1570-71 Tarihinde İrle Kazasındaki Mevkufât

\begin{tabular}{|l|l|l|l|}
\hline Çeşidi & 1501 Yılı & 1530 Y1lı & $1570-71$ Y1lı \\
\hline Çiftlik & 8 & 6 & 11 \\
\hline Bağ-dönüm & 4 & 4 & 4 \\
\hline Bağ-1 Bozyer & - & 1 & 1 \\
\hline Zemin (Dönüm) & 170 & 260 & 263 \\
\hline Nakit Para & - & 9500 & 29720 \\
\hline Ahır & - & - & 1 \\
\hline Cami & 1 & 1 & 3 \\
\hline Mescid & - & 1 & 7 \\
\hline Zaviye & 4 & 4 & 6 \\
\hline Medrese & - & 1 & 1 \\
\hline Su Kuyusu & - & - & 1 \\
\hline Musluk & - & - & 1 \\
\hline Vakf-1 âmm & 2 & 2 & 2 \\
\hline Zamme okumak için kurulan vakıf & 1 & 1 & 1 \\
\hline Vakıflara Kayıtlı Nefer & - & 18 & 22 \\
\hline Vakıflara Kayıtlı Hane & - & 1 & - \\
\hline Çiftlik, zemin, bağ ve nakit para haricinde yazılan hâsıl & 50 & - & 3600 \\
\hline
\end{tabular}

İrle kazasındaki vakıf kurumlarının en önemli ve düzenli gelir getiren kaynaklarının başında tarım işletmeleri gelmektedir. Osmanlı Devleti'nde köyler ve mezraların tamamı veya yarısı vakıf kurumlarına gelir temin edebilmektedir. Sancakta bu tarzda yerler olmasına rağmen kazada köy ve mezraların tahsis edildiğini görmüyoruz. Ancak tarım işletmelerinden biri olan çiftliklerin vakıf kurumlarına gelir getiren işletmeler olduğunu tespit etmekteyiz. 1501'de 8, 1530'da 6 ve 1570-71'de 11 adet çiftlik vakıflara tahsis edilmiştir. Çiftliklerin dışında zemin adı verilen parçalanmış tarlalar ile bağ ve bahçe gibi zirai işletmeler de vakıf gelirleri arasında önemli bir yere sahiptir. Üç tahrirde de 4 dönüm bağ geliri vakıflara ayrılmıştır. Yine Bağ-1 Bozyer'in 1530 ve 1570-71'de vakıflara ayrıldığını görmekteyiz. Zemin olarak kaydedilen arazilerin miktarı 1501'de 170, 1530'da 260 ve 1570-71 y1lında ise 263 dönümdür. Bunların haricinde 1570-71 yılında 1 adet ahır da yapılarak Onacık Dede zaviyesinin hizmetine sunulmuştur (Bk. Tablo 1-2).

Vakıf kuruluşlarına kaynak sağlayan önemli bir vakıf yöntemi de para vakıflarıdır. Para vakıflarının diğer gelirlerden ayırt edici özelliği vakfın mal varlığının tamamen veya bir kısmının nakit para olarak vakfedilmesidir. Yine para vakıfları borç vererek sağladıkları faiz gelirleriyle amaçladıkları faaliyetleri yerine getirmektedirler (Özcan 2003, 10; Ertaş 2007, 190191). Para vakıflarını 1530 ve 1570-71 tarihlerinde görmekteyiz. 1530 yılında İskender Halife medresesine 9500 akçe vakfedilmiştir. 1570-71'de ise medreseye vakfedilen akçe miktarı 5000 akçeye düşmüştür. Ancak bu tarihte birçok vakfa nakit para vakfedildiğini görmekteyiz. Toplam 
11 vakfın gelirleri arasında nakit para vardır. Bunlar "asl-ı mal" şu kadar akçe, "rıbhı" yani paranın işletilmesiyle elde edilen faiz geliri ise şu kadar akçe diye kaydedilmiştir. Bu nakit akçelerin rıbhının (faizinin) imama, müezzine, hatibe, vakfı meremmet (tamir) edene, hızır-1 yatıra ve musluğun suyunu getirip doldurana harcandığını görmekteyiz. Toplamda 29720 akçe nakit para 11 vakfa verilmiştir. Para vakıfları, vakıf kuruluşlarının faaliyetlerinin yürütülmesi için kaynak sağlarken diğer taraftan bölgede yaşayan insanların kredi ihtiyaçlarını da karşılamaktadır. Burada para vakıflarının olması bölgedeki iktisadi hareketliliğin de bir göstergesidir diyebiliriz (Bk. Tablo 1-2).

Kazadaki Zaviyeler: Kazadaki vakıf eserler hakkında bilgi vermek gerekirse, bunların başında zaviyeler gelmektedir. Balkanlar ve Rumeli'nin Türkleşmesi ve İslamlaşmasında tekke ve zaviyelerin önemi büyüktür. Aynı durum Anadolu için de geçerlidir. Özellikle İrle ve çevresi uç bölgesine yakın ve Yörük-Türkmen yerleşmesinin yoğun bulunduğu bir yerdir. Bundan dolayı bölgede zaviyeler çoktur. Hamid Sancağı'nda XVI. asrın başında yüz civarında tekke, zaviye ve hankah vardır ( 88 adet zaviye, 7 tekke ve 2 hankah) (Karaca 2014, 273). 1530 tarihinde ise toplam sancakta 303 vakıf olup 103 adet zaviye ve 5 adet tekke yer almaktadır. Vakıf eserlerde önemli bir artış olmasına rağmen zaviye ve tekkelerde çok artış olmamıştır. Bilindiği gibi tekke ve zaviyeler bir bölgenin iskân ve imarında önemli yapılardır. Yine yeni yerleşme yerlerinin kuruluşunda ve kırsal alanlarda emniyet ve konaklama hizmetlerinde bunların mühim görevleri vardır. Bu bölge uç bölgesinde olduğu ve bahsedilen sebeplerden dolayı çok sayıda tekke ve zaviye kurulmuş ve iskâna ve gelip geçenlere hizmet vermiştir. Belirli bir süre sonra bölgenin iskânı, imarı ve emniyeti gerçekleştiği için sayı artık artmamış ve durağanlaşmıştır. Ayrıca bazı zaviyelerin zamanla buralara yerleşen zümrelerin kişisel çıkarlarına hizmet eder duruma gelmesiyle nesh edilmeleri söz konusu olmuştur. Nesh olanların da bir kısmı sonradan tekrar kurulmamışlardır. Bundan dolayı sancakta sayının sabit kaldığı veya diğer vakıf eserler artarken bunların sayısının artmadığını düşünmekteyiz (TT 438, 250-325; 438 Numaralı Muhasebe-i Vilayet-i Anadolu Defteri (937/1530) 1993, 250-325; Barkan \& Meriçli 1988, 133-144, İnalcık 2000, 170; Yörük 2007, 66). Sancakta çok sayıda bulunan zaviyelerin bir kısmı da İrle'dedir. Özellikle bu zaviye kayıtlarında "ayende ve revendeye" hizmet etmeleri belirtilmiştir. Buradaki zaviyeler, Şeyh İlyas b. Satılmış (karye-i Dere), Şeyh İbrahim (karye-i Akçaköy), Şeyh İshak (karye-i Gölcük), Şeyh İsmail (karye-i İğdir), Onacık Dede (Kargucuk kurbunda) ve Rabia Hatun zaviyeleridir (karye-i Beyler). Görüldügü üzere zaviyelerin birisi kadın ismi taşımakta ve onun tarafından yapıldığını göstermektedir. Kadın tekke ve zaviye şeyhlerini görmek şaşırtıcı olmamalıdır. Çünkü Anadolu'nun fethi, iskânı ve imarında Bacıyan-1 Rum adı altındaki Anadolu kadınlarını ilk dönemlerden itibaren görmekteyiz. İşte bu değerlere sahip kadınların kurduğu tekke ve zaviyeler birçok sancakta yer almaktadır (Barkan \& Meriçli 1988, 143-144).

$\mathrm{Bu}$ zaviyeler içerisinde özellikle Onacık Dede zaviyesinde geçen kayıtlar çok önemli bilgiler vermektedir. Bu zaviye, ilk defa 1570-71 tarihli defterde geçmektedir. Buradaki kayıttan zaviyenin nasıl ve hangi şartlarda kurulduğunu ve işlediğini öğrenmekteyiz. "Mezkûr Onacık Dede seccâde-i nişîn bir aziz olub nahiye-i mezkûrede Karkucuk kurbunda ormandan bir mikdar hâlî yeri kendü çapasiyla açub zâviye ve ahur bina idüb ve köyden üç dönüm mikdarl yer çıkarub zâviyenin çerâğ ve yă̆l içün vakf idüb hal-i hayatda zâviyede sakin olub âyende ve revendeye hidmet idüb vefat itdükden sonra meşîhatı Seraç Dede nâm-ı kimesneye virilüb ba'de meşayihi atam neslinden Ferruh Dede nâm azize virilüb bi'l-fiil zâviyede sakin olub âyende ve revendeye hidmet ider ve aziz-i mezbûrun hal-i huyûtunda nice velâyet ve kerâmeti zâhir olmağın etrafdan nice kimesneler gelüb azizin hidmetinde olub her biri bir hidmete tayin olunub kendüleri vefat idüb oğullar yine zâviyede âyende ve revendeye hidmet itdükleri ecilden zâviyei mezbûreye hidmetkâr kayd olundular sipahi tımarında ziraat ve hıraset etdikleri yerin öşr ve rüsûmun sâhib-i arza eda etdikden sonra bunlara kimesne dahl ve taarruz etmeye" diye kayıt 
edilmiştir (TT 566, 15/b). Bu zaviyeye birçok kişi kaydedilmiş ve "Cemaat-ı Dervişân" şeklinde onlar belirtilmişlerdir. Bunlar arasında imam, türbedar, çırakdar, neğbet, ferraş, saka, çilekeş, neccar, kayyum, tabbah, kilari, mütevelli, çeşmeci, hizmetkâr-1 ahur, müezzin gibi görevleri ifa eden dervişler bulunmaktadır. Bu zaviye ile birlikte Onacık köyü kurulup gelişecektir. Diğer zaviyelerin de geçirdiği tarihi süreç, gelir kalemleri, tasarruf edenleri ve hangi şartları yerine getirecekleri gibi birçok husus defterlerdeki kayıtlarda açıkça belirtilmiştir (Bk. Tablo 2).

Kazadaki Cami ve Mescidler: Cami-i Bedreddin (karye-i Alan), Cami-i Şerif (karye-i Alan), Cami-i Şerif (karye-i Beyler) camileri vardır. Mescidler ise 1530 ve 1570-71 tarihli defterlerde geçmektedir. Mescid-i Yazır, Mescid-i Çardak, Mescid-i Yüreğir, Mescid-i Mahmud Fakih (karye-i Beyler), Mescid-i karye-i Akça, Mescid-i Panbuklu (Pamuklu, karye-i Panbuklu) gibi mescidler bulunmaktadır. Görüldügü üzere mescidler bazı köylere dağılmış durumdadırlar. Büyük köylerde camiler daha küçük yerleşimlerde ise mescidler yer almaktadır.

Beyler köyünde 1530 yılından itibaren bulunan bir medrese vardır. Bu medrese "vakf- $\iota$ medrese-i İskender Halife. Nakdiye 9500, zemin 30 dönüm, bağ-ı Bozyer" diye kaydedilmiştir (TT 438, 263; 438 Numaralı Muhasebe-i Vilayet-i Anadolu Defteri (937/1530) 1993, 263). 1570-71'de ise “Karye-i Beyler'de Muslihüddin oğlu Mevlânâ İskender Halife bir medrese bina idüb medreseye beş bin akçe vakf idüb Bozyer dimekle ma'ruf olan mülk bağı öşrün sipahi aldikdan sonra vakf idüb ve evladından zikr olan medreseye mahall olunduğu vakitde padişahü'l-islam cânibden anlara sadaka oluna ve oğlum Hamza mütevelli ola deyu şart idüb vakfiyesün getirüb defter-i cedide kayd olundu ve nahiye-i mezbûreye kadı olanlar nâzır ola deyu şart eylemiş deyu defter-i atikde mukayyed olmağın defter-i cedide dahi sebt olundu" denilmektedir (TT 566, 17/a).

Yine 1570-71 y1lında karye-i Beyler'de İskender Halife, bina ettiği camiye bir musluk yaptırmış ve beş yüz akçe vakıf etmiştir. Suyu getirip doldurana da yüz akçe verilmesini şart eylemiştir. Görüldüğü üzere kazanın en önemli yeri ve merkezi konumunda olan köy Beyler veya günümüzdeki adıyla Beyköy’dür. Daha önce bahsettiğimiz gibi burada cami, mescid, medrese, musluk ve vakf-1 âmm gibi birçok vakıf ve eser bulunmaktadır (Bk. Tablo 2).

$\mathrm{Bu}$ vakıfların haricinde Çavdır köyünde Eyub Kuyusu vardır. Bu kuyu da buraya hizmet vermektedir (TT 566, 17/a). Kazada bu vakıfların dışında yukarıda bahsettiğimiz üzere çiftlik vakfı, vakf-1 âmm, zamme okumak için yapılan vakıflar bulunmaktadır. Üzerinde durulması gereken hususlardan birisi de Gölhisar nahiyesinde iki adet Rabia Hatun zaviyesine zam edilen yer vardır. Bu vakıflar 1570-71 yılında İrle kazası altında kaydedilmişlerdir. Ancak Gölhisar nahiyesine bağlı oldukları ve Rabia Hatun vakfına zam edildikleri özellikle belirtilmiştir. Mesela bu vakıflardan birinde 1501 tarihinde, "Nahiye-i Gölhisar, karye-i Horzum'da Mustafa b. Hasan Fakih 2 çiftlik vakf yeri var ki merhûmân Murad Han'dan ve Bayezid Han ve Hazret-i Hüdâvendigâr hükümleri muktezâlarınca vakfiyet üzere tasarruf eder deyu defter-i köhnede mukayyed sonra evlâd mutasarrıf olmuş evlâd münkati' olub mezkûr vakf mahlûl olduğu sebebden dergâh-ı mu'allâdan Hasan Fakih b. Kökcü Fakih'e sadaka olub eline hükm-i hümâyûn virildi. Hâsıl 200" denilmektedir. Buradan anladığımıza göre evladı münkatı' (kesilmek, son bulmak) olduğu için vakıf mahlûl (boş) kalmış ve başka birisine verilmiştir (MAD 3331, 69). 1570-71 yılında da Rabia Hatun vakfına zam olmuştur. Bu durum da defterde şöyle belirtilmiştir: "Nahiye-i Gölhisar, karye-i Horzum'da iki çiftlik vakf yer Pir Hasan Çiftliği dimekle ma'rufdur zâviye-i mezbûreye zam olundu deyu defter-i köhnede mukayyed. Hâsıl 400" (TT 566, 17/b).

Yine başka bir kayıtta Gölhisar nahiyesindeki Bügüus köyünde Şeyh Ahmed'in bir çiftlik yerinin mezkûr zaviyeye zam edildiğini öğrenmekteyiz (TT 566,17/b). Aişe Hatun tasarrufunda olan iki çiftlik vakıf yer ile ilgili önemli bilgiler vardır. Bu vakfın Hamidoğulları'ndan kaldığını Aişe Hatun zamanında nesh olup tımara verildiğini, II. Bayezid'in bu vakfın vakfiyetini 
mukarrer tuttuğunu ancak İrle kadısının mezbur Aişe Hatun'un bu vakfın yerlerini satıp zayi etti diye arz etmesiyle padişahın Mevlana Pir Ahmed'e verdiğini belirtmiştir. Bu vakıftan defterde şu şekilde bahsetmektedir: "Aişe Hatun tasarrufunda iki çiftlik vakf yer var imiş Hamidoğlu zamanindan Muslihiddin nâm kimesne vakfi olub vakfiyet üzere tasarruf etmiş fevt oldukdan sonra evlâdl mutasarrıf etmiş evlâdından mezkûr Aişe Hatun tasarrufunda iken nesh olub tımara virilmiş şimdiki halde Padişahü'l-islâm ve'l-müslimîn hazretleri mezkûr vakfin vakfiyyetin mukarrer dutub ve Irle kadısı mezbûr Aişe Hatun vakfin yerlerin satub zâyi' etdi deyu arz etdüğ̈̈ sebebden hükm-i padişahîyle Mevlânâ Pir Ahmed'e sadaka olunmuş. Hâsıl 150” (MAD 3331, 55). Bu vakıf 1530 tarihinde ise kaydedilmemiş, 1570-71 yılında da Beyler köyündeki Rabia Hatun zaviyesine zam edildiği belirtilmiştir. Görüldüğü üzere başka bir vakfa zam edilen vakıfların zam edilme sebebi, vakfın satılması ve zayi edilmesi, vakfın mahlûl kalması, evladının kalmaması yani neslinin kesilmesi gibi sebeplerden kaynaklanmaktadır (TT $566,17 / b)$.

\section{Sonuç}

İrle kazası tahrir ve vakıf defterlerinde geçmesine ve belirtilmesine rağmen bu dönemde İrle isimli bir yerleşim yeri yoktur. Günümüzde İrle, Salda ile Yarışlı Gölü arasındaki mıntıkanın ve ovanın adı olarak bilinmektedir. Ancak, İrle adı XVI. asırda bugünkünden daha farklı bir bölgeyi ifade etmek için kullanılmıştır. İrle, Salda ile Yarışlı Gölü arasındaki ovanın hemen kuzeyindeki Dereköy, Beyköy, Alanköy, Akçaköy, Örencik ve Bayındır köyleri ile Akgöl’ü içine alan bölge ile Hambat yöresini içine alan coğrafyanın adıdır. Vakıf eserler de bu bölgede dağılmış durumdadır. Özellikle de Salda ile Yarışı Gölü arasındaki ovanın kuzeyinde bulunmaktadır. Kazanın merkezi durumundaki Beyler’de (Beyköy) birçok vakıf vardır. Kazada 1501 y1lında 11, 1530'da 12 ve 1570-71'de ise 27 (3 adedi başka bir vakfa zam edildiği için say1 24 'dür) vakıf bulunmaktadır. Buradaki vakıfların cami, mescid, zaviye, medrese, kuyu, musluk, zamme okumak için verilen vakıf, çiftlik, vakf-1 âmm gibi şeylerden meydana geldiğini görmekteyiz. Özellikle zaviye vakıfları burada daha fazladır. Bunun sebebi uç bölgesine yakın olması ve kırsal yerleşmenin hâkim olmasından kaynaklanmaktadır. Bilindiği gibi tekke ve zaviyeler bir bölgenin iskânında, imarında, yeni yerleşme yerlerinin kuruluşunda, kırsal alanlarda emniyet ve konaklama hizmetlerinde önemli yapılardır. İrle kazasındaki vakıf kurumlarının en önemli ve düzenli gelir getiren kaynaklarının başında tarım işletmeleri gelmektedir. Tarım işletmelerinden biri olan çiftliklerin vakıf kurumlarına gelir getiren işletmeler olduğunu tespit etmekteyiz. 1501'de 8, 1530'da 6 ve 1570-71'de 11 adet çiftlik vakıflara tahsis edilmiştir. Çiftliklerin dışında zemin adı verilen parçalanmış tarlalar ile bağ ve bahçe gibi zirai işletmeler de vakıf gelirleri arasında önemli bir yere sahiptir. Üç tahrirde de 4 dönüm bağ geliri vakıflara ayrılmıştır. Zemin olarak kaydedilen arazilerin miktarı 1501'de 170, 1530'da 260 ve 1570-71 yılında ise 263 dönümdür. Vakıf kuruluşlarına kaynak sağlayan önemli bir vakıf yöntemi de para vakıflarıdır. Para vakıflarını 1530 ve 1570-71 tarihlerinde görmekteyiz.

Hamid Sancağı'ndaki vakıfların önemli bir kısmı Hamidoğulları'ndan Osmanlıya intikal etmiştir. Buradaki bazı vakıfların da Hamidoğulları'ndan kaldığı belirtilmiştir. Bu durum devletlerdeki devamlılığı göstermesi açısından önemlidir. Yine bazı vakıfların Fatih Sultan Mehmed döneminde nesh edildiği ve tımara verildiğini görmekteyiz. Bunun sebebi Fatih'in devleti imparatorluk haline getirme yolundaki geniş siyasal emellerini gerçekleştirebilmek için mali kaynakları ile asker sayısını arttırmak ve merkezi otoriteyi güçlendirmek düşüncesindendir. Ayrıca bu amaçlar doğrultusunda birkaç defa tağşiş olayına girişilmiştir. Sonra II. Bayezid döneminde nesh edilen bazı vakıfların tekrar vakıf durumlarının korunduğu bilinmekte ve buradaki vakıf defterlerinde de bununla ilgili örnekler görülmektedir. II. Bayezid'e başa geçerken babasını değil de dedesini örnek almasının söylenmesinin sebebi de bundan kaynaklanmaktadır. Vakıflar, devletlerin sosyo-kültürel durumunu ortaya koyan önemli eserlerden olup 
devletin medeniyete katkısını da belirtmektedir. İrle kırsal bir özellik taşıdı̆̆ı ve merkezinin bulunmamasından dolayı vakıflar köylerde toplanmış durumdadır. Burada kazanın merkezi durumunda olan Beyler'de daha fazla vakıf eser bulunmaktadır. Bundan dolayı da buranın diğer köylere göre sosyal, kültürel, ekonomik ve demografik durumunun biraz daha öne çıttı̆ıını görmekteyiz.

Tablo 2. Vakıf Defterlerine Göre XVI. Yüzyılda İrle Kazası Vakıflarının Dağılımı, Gelir Kalemleri ve Özellikleri

\begin{tabular}{|c|c|c|c|}
\hline No & 1501 Tarihinde Vakıfların Durumu & \begin{tabular}{|l|}
1530 Tarihinde \\
Vakıfların \\
Durumu
\end{tabular} & 1570-71 Tarihinde Vakıfların Durumu \\
\hline 1 & $\begin{array}{l}\text { Karye-i Alan'da kadı Bedreddin kardeşleri } \\
\text { İbrahim Fakih ve İslâm ve Mezid ve Mustafa } \\
\text { bir çiftlik vakf yer tasarruf ederlermiş defter-i } \\
\text { köhnede mukayyed ve ellerinde hükm-i } \\
\text { padişahî vardır deyu defter-i köhnede kayd } \\
\text { olmuş şimdiki halde hazret-i Hüdâvendigâr } \\
\text { mezkûr vakfı mukarrer dutub mezkûrlardan } \\
\text { İslâm ve Mustafa ve müteveffâ olan kadı } \\
\text { Bedreddin oğlu Ahmed Bâlî ve İbrahim } \\
\text { Fakih'in oğlu Halil ve Mezid Fakih oğlu Hızır } \\
\text { Bâlî’ye hükm-i hümâyûn sadaka olunmuş ki } \\
\text { zikr olan bir çiftlik yer ber-karâr-1 sâbık } \\
\text { mutasarrıf olalar vakfiyet üzere mutasarrıf } \\
\text { olalar (sayfa 52). }\end{array}$ & $\begin{array}{l}\text { Vakf-1 be-cihet-i } \\
\text { Baradızân cami-i } \\
\text { Bedreddin } \\
\text { karye-i Alan. } \\
\text { Nefer } 4 \text {, zemin 1 } \\
\text { çiftlik (sayfa } \\
\text { 263). }\end{array}$ & $\begin{array}{l}\text { Karye-i Alan'da kadı Bedreddin karındaşları } \\
\text { İbrahim ve İslâm ve Mezid ve Mustafa bir } \\
\text { çiftlik vakf yer tasarruf idüb mezkûr Kadı } \\
\text { Bedreddin'in oğlu Ahmed ve Bâlî ve } \\
\text { İbrahim Fakih'in oğlu Halil ve karındaşı } \\
\text { Mezid oğlu Hızır Bâlî’ye virilüb oğlu fevt } \\
\text { oldukda oğullarına virildi deyu defter-i } \\
\text { atikde mukayyed hala mezkûrların } \\
\text { evladından İslâm oğlu Mustafa ve K1lıç oğlu } \\
\text { Muhammed ve Mahmud oğlu Şah Veli } \\
\text { biraderi Abdülkadir ve Bayram oğulları } \\
\text { Mahmud ve Muhammed ve Şaban oğlu } \\
\text { Mustafa'ya berât-1 padişahî ile sadaka } \\
\text { olunmuş ber-karâr-1 sâbık mutasarrıf olalar } \\
\text { (sayfa16/a). }\end{array}$ \\
\hline 2 & $\begin{array}{l}\text { Vakf-1 zâviye-i Şeyh İlyas b. Satılmış der } \\
\text { karye-i Dere bir çiftlik yer muâfiyet üzere } \\
\text { tasarruf edüb âyende ve revendeye hizmet eder } \\
\text { imiş ba'de vefata hazret-i Hüdâvendigâr } \\
\text { kıbelinden Muhammed b. Şeyh İlyas'a ve } \\
\text { karındaşı Ali ve Hamza'ya sadaka olunub } \\
\text { mukarrer buyurulmuş defter-i köhnede } \\
\text { mukayyed şimdiki halde hazret-i } \\
\text { Hüdâvendigâr mezkûr vakfin vakfiyyetin } \\
\text { kemâkân mukarrer dutub Ali fevt olub hissesi } \\
\text { oğlu Bayezid'e ve Hamza dahi fevt olub } \\
\text { hissesi mezkûr Muhammedî’yle mezbûr Ali } \\
\text { oğlu Bayezid'e virülüb ellerine hükm } \\
\text { virüldüğ̈ sebebden deftere sebt olundu bir } \\
\text { çiftlik yere vakfiyet üzere mutasarrif olub } \\
\text { âyende ve revendeye hidmet edeler (sayfa 52). }\end{array}$ & $\begin{array}{lr}\text { Vakf-1 } & \text { zâviye-i } \\
\text { Şeyh } & \text { İlyas. } \\
\text { Nefer } & 5 \text {, zemin 1 } \\
\text { çiftlik } & \text { (sayfa } \\
\text { 263). } & \end{array}$ & $\begin{array}{l}\text { Karye-i Dere'de İlyas b. Satılmış bir çiftlik } \\
\text { yeri vakfiyet üzere tasarruf idüb âyende ve } \\
\text { revendeye hidmet ider deyu defter-i } \\
\text { köhnede mukayyed hala nesillerinden } \\
\text { Kökez Eri Hüdâvirdi Hasan ve Ulaş ve } \\
\text { Yusuf'a ve Ömer'e padişahımızı eizza- } \\
\text { Allahu ensâre berât-1 şerif virdügü sebebden } \\
\text { deftere kayd olundu. Hâs1l fi sene } 300 \\
\text { (sayfa 16/a). }\end{array}$ \\
\hline 3 & $\begin{array}{l}\text { Karye-i Akçaköy’de Şeyh İbrahim yeri ki } 40 \\
\text { dönüm zâviyesine vakf imiş defter-i köhnede } \\
\text { mestûr ve ahkâm-1 selâtînde mezkûrdur emr-i } \\
\text { âli mûcebince Paşa Yiğit ve Emre tasarruf } \\
\text { ederler deyu defter-i köhnede mukayyed sonra } \\
\text { tebdîl ve tağyir olub mevkûfcular tasarruf } \\
\text { edermiş şimdiki halde padişahımız halledet- } \\
\text { h1lâfetehü hazretleri vakfiyyetin mukarrer } \\
\text { dutub mezkûr Paşa Yiğit'in eline hükm-i } \\
\text { hümâyûn virüldüğü sebebden deftere sebt } \\
\text { olundu ber-karâr-1 sâbık 40 dönüm yere } \\
\text { vakfiyyet üzere mutasarrif olub âyende ve } \\
\text { revendeye hidmet ede (Emre v. Gaybi, Salih v. } \\
\text { Paşa Yiğit) (sayfa 53). }\end{array}$ & $\begin{array}{l}\text { Vakf-1 zâviye-i } \\
\text { Şeyh İbrahim. } \\
\text { Hane 1, zemin } \\
40 \text { dönüm (sayfa } \\
\text { 263). }\end{array}$ & $\begin{array}{l}\text { Karye-i Akçaköy'de Şeyh İbrahim kırk } \\
\text { dönüm yeri kendü zâviyesine vakf idüb } \\
\text { âyende ve revendeye hidmet olunub tasarruf } \\
\text { olunur deyu defter-i köhnede mukayyed } \\
\text { hala İsa âyende ve revendeye hidmet zikr } \\
\text { olunan yere vakfiyet üzere tasarruf ider bâ- } \\
\text { berâta göre ider. Hâsıl fi sene } 1000 \text { (sayfa } \\
\text { 16/a). }\end{array}$ \\
\hline 4 & $\begin{array}{l}\text { Karye-i Beyler'de Ali Fakih ve Mahmud Fakih } \\
\text { ve Muhammed Fakih ve Mustafa nâm } \\
\text { kimesneler an kadîmü'l-eyyâm } 30 \text { dönüm yere } \\
\text { vakfiyet üzere merhûmân Bayezid } \\
\text { Hüdâvendigâr ve Sultan tâbe serâhumâdan }\end{array}$ & $\begin{array}{l}\text { Vakf-1 Âmm der } \\
\text { karye-i Beyler. } \\
\text { Nefer 3, zemin } \\
\text { 30 dönüm (sayfa } \\
\text { 263). }\end{array}$ & $\begin{array}{l}\text { Karye-i Beyler'de Ali Fakih ve Mahmud } \\
\text { Fakih ve Mustafa nâm kimesneler vakfiyet } \\
\text { üzere } 30 \text { dönüm yere mutasarrıf olalar deyu } \\
\text { defter-i atikde mukayyed hala padişahımı } \\
\text { eizza-Allahu ensâre hazretlerinin berât-1 }\end{array}$ \\
\hline
\end{tabular}


nişân-1 şerîfleriyle mutasarrıflar imiş sonra nesh olub tımara hükm olunmuş şimdiki halde padişahımız eazz-Allahu ensârehu hazretleri vakfiyyetin kemâkân mukarrer dutub mezkûrlarun ellerine hükm-i hümâyûn virüldüğü sebebden deftere sebt olundu ki vakfiyet üzere 30 dönüm yere mutasarrıf olalar deyu (sayfa 53).

5 Karye-i Baraduz'da Şeyh Halil ve kardâş̧ Şeyh İbrahim ile bir çiftlik yer ki defter-i Sultâniyede vakfiyetle mestûr ve mukayyed olub kadîmden selâtîn-i mâzîye ahkâmıyla vakfiyet üzere tasarruf ederler imiş sonra nesh olub tebdîl ve tağyir olmuş şimdiki halde mezkûr vakfin vakfiyyetin kemâkân mukarrer dutdum deyu padişahımız eazz-Allahu ensârehu hazretleri Seyh Halil oğlu Nasuh Fakih'e hükm-i hümâyûn virüldüğü sebebden deftere sebt olundu bir çiftlik yere vakfiyet üzere mutasarrıf ola (sayfa 54).

6 Nâhiye-i Baraduz'da karye-i Gölcük'de Şeyh İshak zâviyesinin bir çiftlik vakf yeri var hükm-i Hüdâvendigâr mûcebince vakfdır ve hem köhne defterde mestûrdur İshak b. Şeyh Muhammed ve Bayezid b. Şeyh Mahmud tasarruflarundadır deyu defter-i köhnede mestûrdur sonra nesh olub tebdîl ve tağyir olmuş şimdiki halde hazret-i Hüdâvendigâr kemâkân mukarrer dutub Şeyh İshak ve Şeyh Bayezid'e hükm-i hümâyûn virüldüğü sebebden kayd olundu ki ber-karâr-1 sâbık bir çiftlik yere vakfiyet üzere mutasarrıf olub âyende ve revendeye hidmet edeler (Vakkas v. Şeyh İshak) (sayfa 54).

7 Nâhiye-i Baradız'da karye-i Kürt'de Melek eşi Ali Bey 60 dönüm yer ve 4 dönüm bâğ yılda bir zamme okumak içün İdris Danişmend'e vakf eylemiş merhûm Sultan Mehmed Han tâbe serâhu nişân-1 şerîfiyle tasarruf edermiş şimdiki halde mezkûr İdris fevt olub oğulları Muhammedî ve İlyas zikr olan 60 dönüm yeriyle ve 4 dönüm bâğ tasarruf edüb yılda bir hatm-1 kelâm edeler (sayfa 54). şerifleriyle Mahmud oğlu Mevlana Sinan'a ve Mehmed el-mezbûr fevt olub Musa oğlu Aydın'a sadaka olundu tasarruf iderler (sayfa16/b).

Vakf-1 be-cihet-i Karye-i Baradız'da Şeyh Halil ve karındaşı Şeyh Halil ve Şeyh İbrahim vakfiyet üzere bir çiftlik yere İbrahim der tasarruf iderler deyu defter-i köhnede mestûr karye-i Baradız. hala Şeyh Halil oğlu Nasuh Fakih'e hükm-i Zemin 1 çiftlik cihân muta' virildiği sebebden deftere kayd (sayfa 263). olundu zikr olan bir çiftlik yere mutasarrıf ola (sayfa 16/b).
Vakf-1 zâviye-i Karye-i Gölcük'de Şeyh İshak zâviyesinin Şeyh İshak. bir çiftlik vakf yeri olub meşîhatı Şeyh Zemin 1 çiftlik Bayezid ve Şeyh İshak ve Mehmed elinde (sayfa 263). $\quad$ olub âyende ve revendeye hidmet ederler deyu mukayyed haliyâ padişahımız vakfiyyetin mukarrer tutub Şeyh Bayezid'e berât-1 hümâyûn virüldüğü sebebden berkarâr-1 sâbık âyende ve revendeye hidmet etmek üzere kemâkân deftere kayd olundu. Hâs1l 500 (sayfa 15/b).
Vakf-1 Ali Bey Nahiye-i Baradız'da karye-i Kürt'de Melek an kıraat-1 eşi Ali Bey altmış dönüm yer ve dört dönüm kelâm-1 kadîm. bağ1 yılda bir zamme okumak içün İdrüs Zemin $\quad 60$ Danişmend'e vakf eylemiş mezkûr İdris fevt dönüm, bağ 4 olub oğulları Muhammedi ve İlyas zikr olan dönüm (sayfa altmış dönüm yeriyle dört dönüm bağ1 263). $\quad$ tasarruf idüb yilda bir hatm okuya deyu defter-i atikde mukayyed hala berât-1 padişahî ile İlyas el-mezbûra sadaka olunub tasarruf idüb bir hatm-i kıraat ide (sayfa $16 / \mathrm{b})$.

8 Yazır köyünde Sevinç Çiftliği Ekmel Fakih'e Vakf-1 be-cihet-i Karye-i Yazır'da Sevinç Çiftliği dimekle ve kardaşı Muhammedî ve Mevlânâ Pir Ekmel Fakih ve ma'ruf çiftliği Ekmel Fakih ve karındaş1 Ahmed ve Mustafa eben an cedd Hamidoğlu Mehmed ve Pir Mehmed ve Pir Ahmed ve Mustafa zamanından berü vakfiyet üzerine tasarruf ede Ahmed der Hamidoğlu zamanından berü vakfiyet üzere gelmişler deyu selâtînü'ş-şahâneden karye-i Yazır. tasarruf ederler deyu defter-i köhnede mukarrernâmeleri var deyu defter-i köhnede Çiftlik-i Sevinç mukayyed hala mezkûrlarun evladından mukayyed sonra tebdîl ve tağyir olmuş şimdiki (sayfa 263). $\quad$ Hızırşah ve Mahmud padişahımız berâtıyla halde padişahımız eazz-Allahu ensârehu hazretleri mezkûr vakfin vakfiyyetin mukarrer dutub Ekmel Fakih ve Pir Ahmed ve Muhammedî ve Yusuf'un ellerine hükm-i hümâyûn virüldüğü sebebden deftere sebt olundu. Hâs1l 50 (sayfa 55).

9 Karye-i İğdir köyünde Şeyh İsmail zâviyesinin Vakf-1 zâviye-i $\quad$ Karye-i İğdir'de Şeyh İsmail zâviyesinin bir bir çiftlik vakf yeri hükm-i Hüdâvendigârda Şeyh İsmail. çiftlik yeri olub Resul oğlu Haydar mezkûr ve köhne defterde mestûrdur el'ân Nefer 6, zemin 1 tasarrufundadır deyu defter-i köhnede Şeyh Musa ve Ersel b. Şeyh Paşa çiftlik (sayfa mukayyed hala vakfiyyetin padişahımız 
\begin{tabular}{|l|l} 
tasarruflarındadır deyu eski defterde mukayyed & 263).
\end{tabular}

şimdiki halde padişahımız eazz-Allahu ensârehu hazretleri kemâkân mukarrer dutub mezkûrlar fevt olub Şeyh Paşa oğlu Şeyh Ersel mahall olduğu sebebden sadaka olunub eline hükm-i hümâyûn virüldügü sebebden deftere sebt olundu (sayfa 55).

10 Aişe Hatun tasarrufunda iki çiftlik vakf yer var imiş Hamidoğlu zamanından Muslihiddin nâm kimesne vakfi olub vakfiyet üzere tasarruf etmiş fevt oldukdan sonra evlâdı mutasarrıf etmiş evlâdından mezkûr Aişe Hatun tasarrufunda iken nesh olub tımara virilmiş şimdiki halde Padişahü'l-islâm ve'l-müslimîn hazretleri mezkûr vakfin vakfiyyetin mukarrer dutub ve İrle kadısı mezbûr Aişe Hatun vakfin yerlerin satub zâyi' etdi deyu arz etdüğü sebebden hükm-i padişahîyle Mevlânâ Pir Ahmed'e sadaka olunmuş. Hâsıl 150 (sayfa 55).

11 Baradız'da karye-i Kürt'de 40 dönüm yer var imiş köhne defterde mestûr hem mülûk-1 mâzîden ve selâtînden mukarrernâmeleri var şimdiki halde Şeyh İlyas oğlu Hızır Fakih tasarrufundadır merhûm Murad Han hükm-i şerîfiyle deyu köhne defterde mukayyed şimdiki halde Hızır Fakih fevt olub oğlu İlyas Fakih'e sadaka olunub eline tecdîd-i hükm-i hümâyûn virilmiş. Hâs1l 100 (sayfa 56). 263).

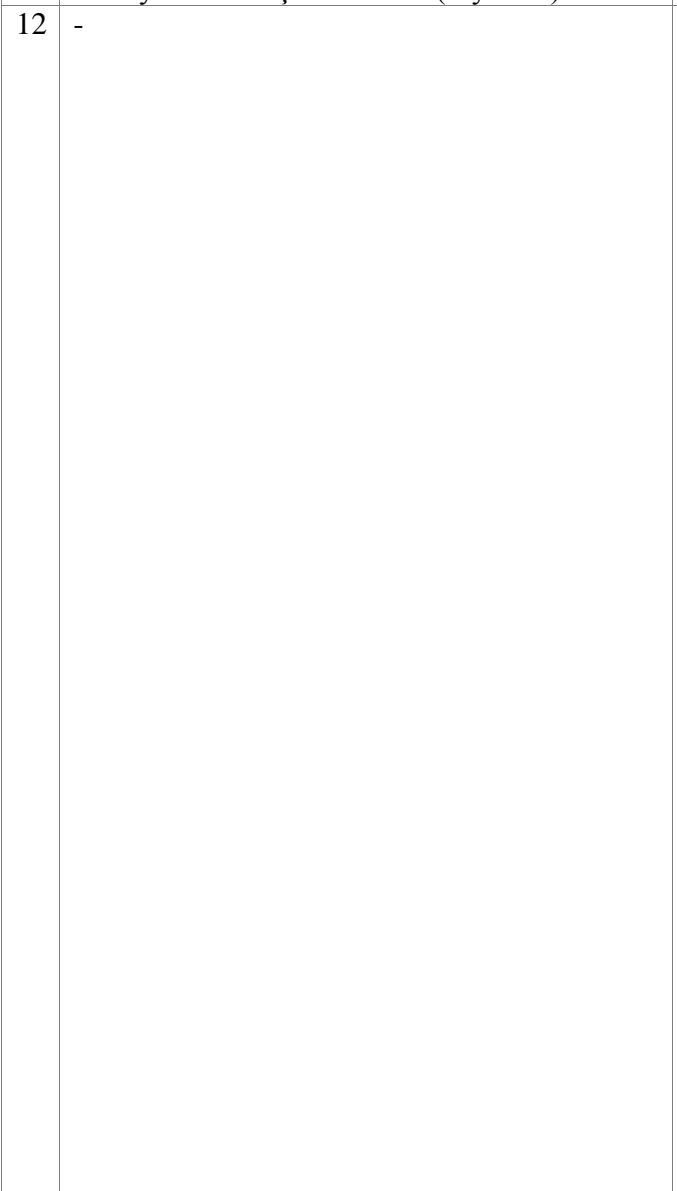

mukarrer dutub İvaz ve Abdi ve Yunus'a ve Timur'a berât-1 hümâyûn sadaka itmeğin deftere kayd olundu. Hâs1l 500 (sayfa 16/a).

Karye-i Bayır'da Aișe Hatun tasarrufunda iki çiftlik vakf yer var imiş Hamidoğlu zamanından berü vakfiyet üzere tasarruf olunur deyu defter-i köhnede mukayyed zâviyeye zamm olundu. Hâsıl 200 (sayfa 17/b).

Vakf-1 Âmm der karye-i Baradiz.

Nahiye-i Baradız'da karye-i Kürt'de kırk 40 İlyas oğlu Hızır Fakih tasarruf ider deyu dönüm (sayfa defter-i köhnede mestur hala padişahımız eizza-Allahu ensâre hazretlerinin nişân-1 serifleriyle oğlu Halil'e sadaka olub tasarruf ider (sayfa16/b).

Vakf-1 Zaviye-i Onacık Dede: Cemaat-1 Dervişân:

Abdülkadir v. Fethullah imam, Mehmed birader-i O türbedâr, Abdülkerim birader-i O çırakdar, Ahmed v. Hamza neğbet, Mehmed v. Nebi ferrâş, birader-i Veled-i O, Çuntar(?) v. Ahmed saka, Mustafa v. Ali çilekeş(?), Abdurrahman v. Ramazan neccâr, Kıdemlü v. Abdullah kayyûm, Hasan v. Musa tabbah, Bali v. Veli kilari, Hasan v. Hamza mütevelli, Veli v. Abdullah çeşmeci, Edhem v. Carullah hizmetkâr-1 ahur, İbrahim v. Seydi müezzin, Emre v. Şirmerd çilekeş, Hasan v. Bahşayış çilekeş, Kıdemlü Yardım Çavuş mu'tak çilekeş, Armağan v. Ali çilekeş, İskender Ferruh Dede mu'tak ferraş, Keşanlu(?) el-mezbûr mu'tak saka.

Mezkur Onacık Dede seccâde-i nişîn bir aziz olub nahiye-i mezkûrede Karkucuk kurbunda ormandan bir mikdar hâlî yeri kendü çapasıyla açub zâviye ve ahur bina idüb ve köyden üç dönüm mikdarı yer çıkarub zâviyenin çerâğı ve yağı içün vakf idüb hal-i hayatda zâviyede sakin olub âyende ve revendeye hidmet idüb vefat itdükden sonra meşîhatı Seraç Dede nâm-1 kimesneye virilüb ba'de meşayihi atam neslinden Ferruh Dede nâm azize virilüb bi'l-fiil zâviyede sakin olub âyende ve revendeye hidmet ider ve aziz-i mezbûrun hal-i huyûtunda nice velâyet ve kerâmeti zâhir olmağın etrafdan nice kimesneler gelüb azizin hidmetinde olub her biri bir hidmete 


\begin{tabular}{|c|c|c|c|}
\hline & & & $\begin{array}{l}\text { tayin olunub kendüleri vefat idüb oğulları } \\
\text { yine zâviyede âyende ve revendeye hidmet } \\
\text { itdükleri ecilden zâviye-i mezbûreye } \\
\text { hidmetkâr kayd olundular sipahi tımarında } \\
\text { ziraat ve hrraset etdikleri yerin öşr ve } \\
\text { rüsûmun sâhib-i arza eda etdikden sonra } \\
\text { bunlara kimesne dahl ve taarruz etmeye } \\
\text { (sayfa 15/b). }\end{array}$ \\
\hline 13 & - & - & $\begin{array}{l}\text { Vakf-1 Mescid-i Yazır tâbi-i İrle. Asl-1 mal } \\
500 \text { ribhı imamla müezzine (sayfa 17/a). }\end{array}$ \\
\hline 14 & - & - & $\begin{array}{l}\text { Vakf-1 Mescid-i Çardak tâbi-i İrle. Asl-1 mal } \\
2100 \text { (sayfa 17/a). }\end{array}$ \\
\hline 15 & - & - & $\begin{array}{l}\text { Vakf-1 Cami-i Şerif der karye-i Alan tâbi-i } \\
\text { mezbûr. Asl-1 mal } 4500 \text { ribhı hatible imama } \\
\text { şüruttur (sayfa 17/a). }\end{array}$ \\
\hline 16 & - & - & $\begin{array}{l}\text { Vakf-1 Eyub Kuyusu der karye-i Çavdır. } \\
\text { Asl-1 mal } 200 \text { (sayfa 17/a) }\end{array}$ \\
\hline 17 & - & - & $\begin{array}{l}\text { Vakf-1 Mescid-i Yüreğir tâbi-i İrle. Asl-1 mal } \\
200 \text { (sayfa 17/a). }\end{array}$ \\
\hline 18 & - & $\begin{array}{l}\text { Vakf-1 medrese-i } \\
\text { İskender Halife. } \\
\text { Nakdiye 9500, } \\
\text { zemin } 30 \text { dönüm, } \\
\text { Bağ-1 Bozyer } \\
\text { (sayfa 263). }\end{array}$ & $\begin{array}{l}\text { Karye-i Beyler'de Muslihüddin oğlu } \\
\text { Mevlânâ İskender Halife bir medrese bina } \\
\text { idüb medreseye beş bin akçe vakf idüb } \\
\text { Bozyer dimekle ma'ruf olan mülk bağ öşrün } \\
\text { sipahi aldıkdan sonra vakf idüb ve } \\
\text { evladından zikr olan medreseye mahall } \\
\text { olunduğu vakitde padişahü'l-islam cânibden } \\
\text { anlara sadaka oluna ve oğlum Hamza } \\
\text { mütevelli ola deyu şart idüb vakfiyesün } \\
\text { getirüb defter-i cedide kayd olundu ve } \\
\text { nahiye-i mezbûreye kadı olanlar nâzır ola } \\
\text { deyu şart eylemiş deyu defter-i atikde } \\
\text { mukayyed olmağın defter-i cedide dahi sebt } \\
\text { olundu (sayfa 17/a). }\end{array}$ \\
\hline 19 & - & - & $\begin{array}{l}\text { Vakf-1 Cami-i Şerif der karye-i Beyler tâbi-i } \\
\text { İrle. } \\
\text { Asl-1 mal } 8000 \text { rıbhı imamla hatibe } \\
\text { meşruttur. } \\
\text { Asl-1 mal } 1000 \text { ribhı müezzine meşruttur. } \\
\text { Asl-1 mal } 300 \text { ribhı meremmet edene } \\
\text { meşruttur (sayfa 17/a). }\end{array}$ \\
\hline 20 & - & - & $\begin{array}{l}\text { Vakf-1 Mescid-i Mahmud Fakih der karye-i } \\
\text { mezbûr. Asl-1 mal } 300 \text { ribhı imama meşrut } \\
\text { (sayfa 17/a). }\end{array}$ \\
\hline 21 & - & - & $\begin{array}{l}\text { Vakf-1 Zâviye-i Râbia Hatun der karye-i } \\
\text { mezbûr. Asl-1 mal 4400, hızır-1 yatır bâ- } \\
\text { berât, İlyas zâviyedâr bâ-berât (sayfa 17/b). }\end{array}$ \\
\hline 22 & - & - & $\begin{array}{l}\text { Vakf-1 Mescid-i karye-i Akça tâbi-i İrle. Asl- } \\
1 \text { mal } 2720 \text { ribhı imama meşrut (sayfa 17/b). }\end{array}$ \\
\hline 23 & - & - & $\begin{array}{l}\text { Vakf-1 karye-i Beyler'de mezkûr İskender } \\
\text { Halife bina itdüğü cami-i mezkûre bir } \\
\text { musluk bina idüb beşyüz akçe vakf idüb } \\
\text { suyun getirüb doldurana yüz akçe vakf } \\
\text { itmişdir ber-mûceb-i ciheti yine kemâkân } \\
\text { mukarer (sayfa 17/b). }\end{array}$ \\
\hline 24 & - & - & $\begin{array}{l}\text { Karye-i Beyler imamı vakfiyet üzere tasarruf } \\
\text { ide geldüğ̈ } 30 \text { dönüm mikdarı yerdir deyu } \\
\text { kadı mektubuyla i'lam iken mescid-i } \\
\text { mezbûreye yine kemâkân mukarrer (sayfa } \\
\text { 17/b). }\end{array}$ \\
\hline 25 & - & $\begin{array}{l}\text { Vakf-1 be-cihet-i } \\
\text { imam-1 karye-i } \\
\text { Panbuklu. Zemin }\end{array}$ & $\begin{array}{l}\text { Vakf-1 Pamuklu Mescidi'nin imamı vakfiyet } \\
\text { üzere } 60 \text { dönüm yer tasarruf ider deyu kadı } \\
\text { mektub virmişdir yine kemâkân mukarrer }\end{array}$ \\
\hline
\end{tabular}




\begin{tabular}{|c|c|c|c|}
\hline & & 60 dönüm. S.263. & (sayfa 17/b). \\
\hline 26 & $\begin{array}{l}\text { Nahiye-i Gölhisar, Karye-i Büğüş'de Şeyh } \\
\text { Ahmed bir çiftlik yer vakfiyet üzere tasarruf } \\
\text { edermiş merhûm sultan Muhammed Han tâbe } \\
\text { serâhu nişân-1 şerîfiyle oğlu Şeyh Mustafa } \\
\text { mutasarrıf imiş sonra nesh olmuş şimdiki halde } \\
\text { padişahımız eazz-Allahu ensârehu hazretleri } \\
\text { vakfiyetin kemâkân mukarrer dutub mezkûr } \\
\text { Mustafa fevt olub oğlu Şeyh Süleyman'a } \\
\text { sadaka edüb eline hükm-i hümâyûn verildüğü } \\
\text { sebebden deftere sebt olundu (sayfa 61)*. }\end{array}$ & - & $\begin{array}{l}\text { Nahiye-i Gölhisar, karye-i Büğüş’de Şeyh } \\
\text { Ahmed bir çiftlik yer vakfiyet üzere tasarruf } \\
\text { ider imiş zâviye-i mezbûreye zamm olundu } \\
\text { deyu defter-i köhnede mukayyed. Hâs1l } 200 \\
\text { (sayfa 17/b). }\end{array}$ \\
\hline 27 & $\begin{array}{l}\text { Nahiye-i Gölhisar, Karye-i Horzum'da } \\
\text { Mustafa b. Hasan Fakih } 2 \text { çiftlik vakf yeri var } \\
\text { ki merhûmân Murad Han'dan ve Bayezid Han } \\
\text { ve Hazret-i Hüdâvendigâr hükümleri } \\
\text { muktezâlarınca vakfiyet üzere tasarruf eder } \\
\text { deyu defter-i köhnede mukayyed sonra evlâd } \\
\text { mutasarrıf olmuş evlâd münkati’ olub mezkûr } \\
\text { vakf mahlûl olduğu sebebden dergâh-1 } \\
\text { mu'allâdan Hasan Fakih b. Kökcü Fakih'e } \\
\text { sadaka olub eline hükm-i hümâyûn virildi. } \\
\text { Hâs1l } 200 \text { (sayfa 69)*. }\end{array}$ & - & $\begin{array}{l}\text { Nahiye-i Gölhisar, karye-i Horzum'da iki } \\
\text { çiftlik vakf yer Pir Hasan Çiftliği dimekle } \\
\text { ma'rufdur zâviye-i mezbûreye zamm olundu } \\
\text { deyu defter-i köhnede mukayyed. Hâsıl } 400 \\
\text { (sayfa 17/b). }\end{array}$ \\
\hline
\end{tabular}

Not: * Bu vakıf 1501 yılında Gölhisar nahiyesine kayıtlı olup bu nahiye altında kaydedilmiştir. Ancak 1570-71'de İrle vakıfları altında kaydedilmiş ve Gölhisar nahiyesinde olduğu belirtilmiştir.

\section{Yazar Notu}

Bu makale, 11-14 Temmuz 2019 tarihleri arasında Bandırma'da düzenlenen V. Uluslararas1 Sosyal ve Eğitim Bilimleri Araştırmaları Kongresi'nde sunulan bildiri metninin genişletilmiş ve gözden geçirilmiş şeklinden oluşmaktadır.

\section{KAYNAKÇA}

\section{Arşiv Vesikaları}

BOA, TT 994.

BOA, TT 121.

BOA, TT 438.

BOA, KK 3357.

BOA, MAD 14.

TKGMA, TT 51.

TKGMA, TT 566.

\section{Yayınlanmış Vesikalar}

438 Numaralı Muhasebe-i Vilayet-i Anadolu Defteri (937/1530), C. I, Kütahya Karahisar-1 Sahib, Sultanönü, Hamid ve Ankara Livaları, T.C. BDAGMOADB, Ankara, 1993, s. 246-331.

\section{Kaynak ve Araştırma Eserleri}

Ahmed Refik (1340). "Fatih Zamanında Teke-ili”. TTEM 14/2/79 (1340) 65-76.

Akgündüz A. (1988). İslam Hukukunda ve Osmanlı Tatbikatında Vakıf Müessesesi. Ankara 1988.

Arıkan Z. (1988a). XV-XVI. Yüzylllarda Hamit Sancağı. İzmir 1988.

Arıkan Z. (1988b). "Hamit Sancağındaki Tımar Düzenine Toplu Bakış". IX. Türk Tarih Kongresi Ankara 21-25 Eylül 1981 Kongreye Sunulan Bildiriler. Cilt II. (1988b) 879-885. Ankara.

Barkan Ö.L. \& Meriçli E. (1988). Hüdavendigar Livası Tahrir Defterleri I. Ankara 1988.

Cezar M. (2010). Mufassal Osmanlı Tarihi Resimli Haritalı I. Ankara 2010.

Ergin O. (1939). Türk Şehirciliğinde İmâret Sistemi. İstanbul 1939. 
Ertaş M. Y. (2012). "XV.-XVI. Yüzyıllarda Hambat Yöresinde Yerleşim ve Nüfus”. Pamukkale Üniversitesi Sosyal Bilimler Enstitüsü Dergisi 11 (2012) 153-167.

Ertaş M. Y. (2007). XV.-XVI. Yüzyllarda Karaağaç-ı Gölhisar (Acıpayam) Kazası. İstanbul 2007.

İnalcık H. (1997). "Mehmed II". IA VII (1997) 506-535.

İnalcık H. (2000). Osmanlı İmparatorluğu’nun Ekonomik ve Sosyal Tarihi. Cilt I. İstanbul 2000.

Karaca B. (2001). "XVI. Yüzyılda Eğirdir ve Çevresinde Konar-Göçerler (Yörükler)”. Tarihi Kültürel Yönleri ile Eğirdir. 1. Eğirdir Sempozyumu (31 Ağustos-1 Eylül 2001). (2001) 457-472. Isparta.

Karaca B. (2002a). XV. ve XVI. Yüzylllarda Teke Sancăğ. Isparta 2002.

Karaca B. (2002b). "Safevi Devleti’nin Ortaya Çıkışı ve II. Bayezid Dönemi Osmanlı-Safevi İlişkileri”. Türkler IX (2002) 409-418.

Karaca B. (2003). "Yavuz Sultan Selim Dönemi Osmanl1-Safevi İlişkileri”. SDÜ Fen-Edebiyat Fakültesi Dergisi 9 (2003) 71-86.

Karaca B. (2005). "Osmanlı Devleti'nde Konar-Göçer Zümrelerin (Yörükler) Safevi Devletiyle İlişkileri”. Arayış̧lar-İnsani Bilimleri Araştırmaları 14 (2005) 17-36.

Karaca B. (2007a). "XVI. Asırda Batı Toroslar'da (Güneybatı Anadolu) Yörükler". Uluslararası Denizli ve Çevresi Tarih ve Kültür Sempozyumu Bildirileri I (2007) 111-124. Denizli.

Karaca B. (2007b). "XVI. Yüzyılda Gölhisar Kazasının Sosyal ve Ekonomik Durumu". 1. Burdur Sempozyumu Bildiriler (16-19 Kasım 2005) I (2007) 759-774. Burdur.

Karaca B. (2012). XV. ve XVI. Yüzylllarda Uluborlu Kazast. Isparta 2012.

Karaca B. (2014). 1501'de Hamid Sancă̆l Vakıflarl (Mad 3331 Numarall Vaklf Defterinin Transkripsiyonu ve Değerlendirmesi). Burdur 2014.

Karaca B. (2017). “Teke Yöresinden Safevi Devleti’ne Göçler”. Ed. O. Köse, Geçmişten Günümüze Göç I (2017) 577-593. Samsun.

Kazıcı Z. (2003). Osmanlı Vakıf Medeniyeti. İstanbul 2003.

Kofoğlu S. (2006). Hamidoğulları Beyliği. Ankara 2006.

Ortaylı İ. (2007). Türkiye Teşkilat ve İdare Tarihi. Ankara 2007.

Osmanlı Teşkilat Tarihi El Kitabı. (2012). Ed. Tufan Gündüz. Ankara 2012.

Özcan T. (2003). Osmanlı Para Vakıfları Kanuni Dönemi Üsküdar Örneği. Ankara 2003.

Öztürk N. (2002). “Osmanlı Döneminde Vakıflar”. Türkler X (2002) 433-446.

Saydam A. (1995). Osmanlı Medeniyeti Tarihi. Trabzon 1995.

Tekindağ Ş. (1997). "Karamanlılar”. IA VI (1997) 316-330.

Uzunçarşılı İ. H. (1984). Anadolu Beylikleri ve Akkoyunlu, Karakoyunlu Devletleri. Ankara 1984.

Ünal M. A. (2013). Osmanlı Müesseseleri Tarihi. Isparta 2013.

Yediyıldız B. (1982). "Müessese Toplum Münasebetleri Çerçevesinde XVIII. Asır Türk Toplumu ve Vakıf Müessesesi”. VD XV (1982) 23-54.

Yediyıldız B. (1999). “Osmanlılar Döneminde Türk Vakıfları ya da Türk Hayrat Sistemi”. Osmanlı V (1999) 17-33.

Yörük D. (2007). “Karaman Eyaletinde Tımara Çevrilen Vakıf ve Mülkler (1476-1483)”. Hacettepe Üniversitesi Türkiyat Araştırmaları (HÜTAD) VI (2007) 61-74.

Yüksel H. (2002). "Türk Toplumunda Vakıf Aile İlişkisi”. Türkler X (2002) 461-469.

Yüksel H. (1999). “Osmanlı Toplumunda Vakıflar ve Kadın (XVI-XVII. Yüzyıllar”. Osmanlı V (1999) 49-55. 